\title{
"In a Sea of Wonders:” Eastern Europe and Transylvania in the Irish-Language Translation of Dracula
}

\author{
Sorcha DE BRÚN \\ University of Limerick (Limerick, Ireland) \\ School of Irish, English and Communication \\ Sorcha.debrun@ul.ie
}

\begin{abstract}
The publication of the Irish-language translation of Dracula in 1933 by Seán Ó Cuirrín was a landmark moment in the history of Irishlanguage letters. This article takes as its starting point the idea that language is a central theme in Dracula. However, the representation of Transylvania in the translation marked a departure from Bram Stoker's original. A masterful translation, one of its most salient features is Ó Cuirrín's complex use of the Irish language, particularly in relation to Eastern European language, character, and landscapes. The article examines Ó Cuirrín's prose and will explore how his approaches to concrete and abstract elements of the novel affect plot, character, and narration. The first section explores how Dracula is treated by Ó Cuirrín in the Irish translation and how this impacts the Count's persona and his identity as Transylvanian. Through Ó Cuirrín's use of idiom, alliteration, and proverb, it will be shown how Dracula's character is reimagined, creating a more nuanced narrative than the original. The second section shows how Ó Cuirrín translates Jonathan Harker's point of view in relation to Dracula. It shows that, through the use of figurative language, Ó Cuirrín develops the gothic element to Dracula's character. The article then examines Ó Cuirrín's translations of Transylvanian landscapes and soundscapes. It will show how Ó Cuirrín's translation matched Stoker's original work to near perfection, but with additional poetic techniques, and how Ó Cuirrín created a soundscape of horror throughout the entirety of the translation.
\end{abstract}

Keywords: Seán Ó Cuirrín, Bram Stoker, Dracula, Irish-language translation, an Gúm, gothic, Transylvania 


\section{Dracula as Gaeilge}

The publication in 1933 of the Irish-language translation of Dracula (Stoker 1897) by native Irish speaker Seán Ó Cuirrín (1894-1980) was a landmark moment in the history of Irish-language letters. Written under the auspices of scéim aistriúcháin an Ghúim, ${ }^{1}$ the novel was translated by Ó Cuirrín as part of the translation scheme established by the government of the new Irish state after independence (Cronin 1993). It was from the Waterford Irish-speaking district, or Gaeltacht, that Seán Ó Cuirrín - translator, teacher, and writer - hailed. Ó Cuirrín translated Tolstoy's 1872 short story "God Sees the Truth, But Waits" to "An deoruidheacht fhada" [The Long Exile] (Ó Cuirrín 1936) from the Russian "Bog pravdu vidit da ne skoro skazhet"; Washington Irving’s Rip Van Winkle (1819) to Rip Bhan Bhuincil (Ó Cuirrín 1936); as well as authoring short stories such as "Beirt Dhéiseach" [Two Natives of Waterford] (Ó Cuirrín 1936) and a satirical work, Psaltair na Rinne [The Psalter of Ring] (1938). In their catalogue of translations by An Gúm, Mag Shamhráin and Ó Faracháin (2003) detail other works translated during this period of intense activity. The translators were generally accomplished writers themselves: writers such as Máirtín Ó Cadhain, Seosamh Mac Grianna, and Seán Mac Maoláin translated works by Charles Kickham, Charles Dickens, William Carlton, Standish O'Grady, and Joseph Conrad amongst others (Uí Laighléis 2003).

The first Irish-language edition of Dracula was a bestseller and an instant success. That same success, and the achievements of other Irish-language translations, was a contributory factor not only to the development of modern Irish literature in the years that followed but also to the generations of Irish readers who were to come, to the legacy of translation in Irish-language literature and to the gothic mode in Irishlanguage literature and drama. The objective of the scheme was to provide world classics to the Irish-language reading public (Titley 1990, 67), speakers of a language that was once the lingua franca of Ireland but which had been in retreat to Irishspeaking districts over the preceding centuries and whose demise was hastened by the Great Famine (1845-1848). Yet the ultimate beneficiary of the Scheme was Irish-language literature (Ó Conchubhair 2011). One could claim, with justification, that the Irish translation of Dracula encapsulates a happy marriage between the experience of literature as that which "infiltrates and informs our lives" (Felski $2008,5)$ to reading in Irish as a communal aesthetic experience.

Brilliant as the Irish translation is, Ó Cuirrín made significant changes to several features of Dracula. These changes mostly relate to plot. One of the most noteworthy examples of plot development in Bram Stoker's original was his use of

1 Scéim aistriúcháin an Ghúim translates as An Gúm translation scheme. An Gúm refers to the Irish Government publishing company which published the scheme's Irish-language translations. An Gúm has since been amalgamated into the state body with responsibility for the Irish language, Foras na Gaeilge [The Irish Language Body]. 
intertextuality. Stoker's references to the Shakespearian dramas King Lear, Macbeth, The Merchant of Venice, and Hamlet were omitted by Ó Cuirrín or else replaced with quotations from Irish-language literature of an earlier period (de Brún 2007). It is worth noting that translated texts are not always aligned to the lexical meaning of Stoker's original text. In one case, for example, Stoker includes a tragic reference to the death of Ophelia, lying with "virgin crants and maiden strewments" (Stoker 1996, 132), a harbinger of what is to befall Lucy Westenra. This is replaced by Ó Cuirrín with a quotation from Brian Merriman's eighteenth-century Irish-language poem “Cúirt an Mheán Oídhche” [“The Midnight Court”] (circa 1780) "ag súil trém chodladh le cogar óm chéile” (Stoker 1997, 135) [expecting, as I sleep, a whisper from my lover]. ${ }^{2}$ While both the English original and the Irish translation reference sleep and virginity, the Shakespearian reference in Stoker's novel is imbued with a sense of Ophelia's impending death. The Merriman quotation, however, is an overt allusion to female desire. Intertextual references such as this in the Stoker original contain layered literary allusions and function as plot indicators, but Lucy's impending doom is lost in the rambunctiousness of Merriman's line. The implications of Ó Cuirrín's decision were a shift towards story "as events" (Chatman 1978) and a shift away from narrative discourse. In addition, the Socratic dialogues and the "céimeanna argóna" [constructions of argument] that comprise the dialogues in Dracula (de Brún 2007, 83), so beloved of Dracula and Van Helsing, largely go untranslated in Ó Cuirrín’s work (de Brún 2007). Another noteworthy feature of Stoker's original is the myriad references to classical Greek and Roman mythology. Amongst the intertextual references in Stoker's novel, for example, was Homer's The Odyssey (de Brún 2009, 113). And although Meyer (1952, 78) notes that there was a process of "transmission" of sections of The Odyssey to Irish, it is noteworthy that the reference to this work from classical antiquity was not translated by Ó Cuirrín. As with the Shakespearian plays, references in the original to the underworld of the River of Lethe and Medusa's snakes served to heighten the concept of Dracula's castle as an underworld populated by the Undead (de Brún 2009). ${ }^{3}$ But Ó Cuirrín's omission of those same classical allusions, while posing questions regarding the rationale for their absence, are counterbalanced by a unique approach to Dracula's character as quintessential Irish-Transylvanian Count and to the idea of Transylvania itself. His 1933 Irish translation was followed by new editions in 1997 and in 2014, but the fundamentals of the original translation remained. As in the 1933 edition, aspects of character, description, and dialogue are subtly altered to an extent that reshapes the concepts of Transylvania and the foreignness in Dracula.

2 This translation and the following translations from Irish literature are my own throughout the article.

3 Kiberd (2006) refers to the "Undead," whereas Haining and Tremayne (1997) refer to the "Undead." 


\section{Dracula and Language}

Language is one of the central themes in Dracula, and different forms of the spoken and written word are discussed frequently, from "slang" (Stoker 1996, 58) to "analogy" (Stoker 1996, 269). It is a lens through which the translation can be examined, giving us as it does a multi-layered insight into the novel when read in conjunction with the gothic mode. "The sea of wonders" (Stoker 1996, 18) to which Jonathan refers in the early stages of the novel, an ambiguous statement which hints at his enchantment with as well as his terror of Dracula, is translated by Ó Cuirrín as "blinded," "dallta" (Stoker 1997, 24). That notion of blindness, of not being able to believe one's eyes, serves to emphasize the importance of listening and of sound in the novel as alternative means of sense perception. In addition, it is an indication of the centrality of dialects, accents, and second-language use. Dracula is a collection of multiple modalities and multiple perspectives. The only point of view that we do not encounter directly is that of Dracula himself. That increasing chaos and loss of language, and the novel's plethora of languages half spoken and barely comprehended, is reminiscent of the Tower of Babel to which Stoker alludes (Stoker 1996, 310). The unreliability and the unpredictability of language increase as the novel progresses.

It is in the company of Dracula himself that we first bear witness to the inscrutability of language, particularly when the Transylvanian Count speaks English to Jonathan Harker in their initial meetings. In an entry from Mina's journal, we read how she relates a story told to her by Van Helsing, where a port official describes, in his Cockney dialect rendered by Stoker through the official's use of the slang word "bloomin" (Stoker 1996, 318), how Dracula speaks many languages and is a polyglot (Stoker 1996, 318). Language is the subject of Dracula and Jonathan's first conversations in the novel, and language use is reinforced by Jonathan's journey to the Castle and to his hearing many languages (6), or "ilteangacha" [many languages] in Ó Cuirrín's translation (Stoker 1997, 7). Indeed, at a later stage in the novel, Dracula's study of many languages is noted by Van Helsing when he says of the Count: "He study many tongues" (Stoker 1996, 321). The elusive nature of Dracula's native language in Transylvania is supported here by indirect narration, where linguistic multiplicity is represented by layering of narrative accounts. In this way, the novel presents us not merely with an unreliable narrator but with the obfuscation of several unreliable narrators. These unreliable narrators highlight the gap between what Jonathan and Van Helsing call "facts" (Stoker 1996, 30) and the unfathomable experiences of the emotional turmoil they are going through.

At times, Ó Cuirrín's translation renders Dracula, presented by Stoker as a tale of an international "criminal" (Stoker 1996, 342), as a more localized story of magic and mystery. For example, Ó Cuirrín refers to magic, "draíocht” (Stoker 1997, 42), where Stoker refers to "gloom" in the English original (Stoker 1996, 33). The ghost story is 
underscored by Ó Cuirrín’s reference to the ghostly spirit, “spiorad ná púca” (Stoker 1997, 35), where Stoker makes no reference to that in the corresponding English passage. Similarly, in Count Dracula's discussion of the history of Transylvania with Harker, Ó Cuirrín uses references to the transmission of folklore, "seanchas" (Stoker 1997, 37), where Stoker simply writes “conversation” (Stoker 1996, 28). Dracula cautions Jonathan about Transylvania in the following line from Stoker's novel: "It is more dangerous than you think in this country" (Stoker 1996, 26). Ó Cuirrín replaces "country" with "dúiche" [native place] in the Irish translation (Stoker 1997, 33). That alteration from the national/international to the local is achieved in two ways, and notably in the parts of the novel where Jonathan and Dracula discuss what it means to be a foreigner in London or a "stranger" (Stoker 1996, 20) from Transylvania. Firstly, in his translation of concrete descriptions of Dracula, Ó Cuirrín renders him a friendlier figure than that in Stoker's original and omits many of Dracula's monologues about the genealogy and nobility of his Transylvanian line. Secondly, although Dracula is a foreign speaker of English in Stoker's original, Ó Cuirrín's Irish translation portrays the Count as a fluent speaker of Irish, entirely at ease with the language and using the same register as Jonathan Harker.

\section{Count Dracula: Dialogue and Speech}

Perhaps the most noteworthy change that was made by Ó Cuirrín in the Irishlanguage translation was that of Count Dracula's character. Ó Cuirrín achieves this through manipulation of the Count's dialogue and descriptions from Jonathan's point of view of Dracula's physical appearance. Through using various literary devices, techniques, and changes in register, Count Dracula's character in the Irish translation is never quite as vicious or as cruel as in the original. The single most salient feature of Dracula's dialogue with Jonathan Harker is that of language interference, where Dracula's native language in Transylvania interferes with his use of English. This means that the Count speaks English using a more formal register (Biber 2009) than that used by Jonathan. That formal register in the English original, of course, is also indicative of the Count's past as a Transylvanian noble, where he claims that he is "of an old family" (Stoker 1996, 23) and that "[w]e Transylvanian nobles love not to think that our bones may be amongst the common dead" (Stoker 1996, 24). When Jonathan praises him for his English, the Count reminds him that he will be using Jonathan to practise his English in preparation for his trip to London. It is noteworthy that language is portrayed by Stoker as a subject for exploitation, in much the same way that Dracula intends to feed on Jonathan's blood.

In contrast, Ó Cuirrín's translation depicts Dracula as a fluent speaker of Irish, speaking in an informal register to Jonathan Harker. When the Count bemoans how his heart is "not attuned to mirth" (Stoker 1996, 24), the Irish translation depicts 
Dracula as a fluent speaker of Irish, knowledgeable and skilful in his use of native speaker idioms and phraseology: “Tá an óige ar mo chúl agus an bás ar m’aghaidh; agus meidhir ná greann, ní taithíoch le mo chroí ach cumha ó shíorchaoineadh na marbh leis na blianta fiara fuara anuas" (Stoker 1997, 30). [Youth is behind me, and death is before me; and my heart has not experienced joyfulness nor humour but rather the homesickness of the constant crying of the dead for many cold long years now]. A further dichotomy between the English formal register and the Irish informal one can be seen in a stunning passage which highlights Ó Cuirrín's fluency with the intricacies of Irish and of literary prose techniques. For example, whereas the English original describes his books as providing Dracula with many hours of pleasure (Stoker 1996, 20), Ó Cuirrín translates this to the more casual pastime, or "caitheamh aimsire" (Stoker 1997, 25). In translating Dracula's statement that "to know her is to love her" (Stoker 1996, 20), Ó Cuirrín uses the phrase "ní hionúine go haitheantas" (Stoker 1997, 25) [it is not love until it is knowledge]. While the sentiment remains the same, what is striking about the passage is the use of the oppositional proverb structure, as described by Dundes and Mieder (1994), something that could only be used by a fluent and gifted native speaker in an informal register. Ironically, it is Dracula's insistence on his identity as a foreigner, as a "stranger" (Stoker 1996, 20), that is belied in the Irish-language translation by the proliferation of what has been identified as an imperative-negative structure (Ajoke et al. 2015). Ó Cuirrín uses amplification in Dracula's speech to express his concept of the foreigner, the emphasis on the negative "ní" echoing Mullan's assertion that amplification is "often more like drama than narrative” $(2006,234)$. In addition to comprising parallelism, where the adjectives and nouns suarach [insignificant], haithnidh [acquaintance], neamhshuim [disinterest], and neamhaitheantas [unacquainted] are emphasized to rhetorical effect, this amplification reminds us that, in the words of Hebron, "our division of sound and grammar is artificial" $(2004,70)$. In addition to the altered meaning of the passage, the Irish-language construction uses the negative to express the positive, whereas the English language original is unitary in conveying a negative idea: "But a stranger in a strange land, he is no one; men know him not - and to know not is to care not for" (Stoker 1996, 20); "Ach an coigríochach i dtír aineoil - ní suarach go dtí é; ní haithnidh d'éinne é, agus ní neamhshuim go neamhaitheantas” (Stoker 1997, 26) [But the stranger in a foreign land - you have not seen insignificant until you see him; nobody will recognize him; and you only understand disinterest until you understand what it is to be unknown].

Dracula employs the same oppositional Irish-language proverb structure when he describes the peasants of Transylvania as "ní hamadán meata go tuathánach é” (Stoker 1997, 28) [you haven't met a fool until you have met a peasant] as a translation for “[b]ecause your peasant is at heart a coward and a fool!” (Stoker 1996, 22). Ó Cuirrín’s use of alliteration in Dracula's monologues with Harker in the early chapters of the novel are an indication of a fluent speaker of Irish, and not just one who is, as Dracula states 
in the original, "but a little way on the road I would travel" (Stoker 1996, 20). Dracula describes how "none there are who would not know me for a stranger" in London, a clear example of second-language interference, which Ó Cuirrín translates as "lom láithreach" (Stoker 1997, 26) [baldly, at once] to express immediacy of recognition. Similarly, Ó Cuirrín uses the phrase "beatha ná béasa" (Stoker 1997, 27) to express "our ways are not your ways" when Dracula compares Transylvania to England. This is a further exploration of Ó Cuirrín's use of alliteration in Irish-language sayings and figures of speech, where alliteration is a feature of what Ajoke et al. (2015) describe as the semantic proverb. It is ironic, therefore, that their conversation, while rendered coherently in the Irish translation, is centred around books and fluency yet lacks fluency in the English original. In contrast, Dracula's voice in the Irish translation indicates fluency and native speaker ease with complex constructions. This is a case where, as Mullan notes, "[f]iction may turn the speech of its characters into the language of its readers" $(2006,140)$. And while the English original is faithful in its rendition of Dracula as non-native speaker, the Irish translation achieves just the opposite: Dracula is as skilled a raconteur as any elderly native of the Gaeltacht in these passages. The glorious and noble past of the Transylvanian Count is rendered as a friendly old man seated beside the fire with his confidant. In Ó Cuirrín's hands, the Count's rendition of this "noble" past is augmented to a conversation between new acquaintances who might just become friends.

\section{Dracula: Irish-Transylvanian Count}

The passages in which Dracula is described in detail are perhaps amongst the greatest achievements in the Irish translation. Some of these passages describe Dracula as "our old fox" (Stoker 1996, 292), translated as "seanmhadra rua" [old red fox] (Stoker 1997, 270). Others relate to Jonathan's physical description of Dracula as he sits by the fire, watched nervously by his new guest. These concise passages feature flashes of comic writing not evident in the English original and highlight what Mullan refers to in his discussion of translation and prose writing, when "the business of translation is sometimes inadvertently comic" (2006, 138). And yet, despite the humorous tenor of the piece, there are undertones to these descriptions which function as a precursor to the plot. This stands in contrast to Ó Cuirrín's omissions, as noted above, of classical and Shakespearian references. As is the case throughout the novel, Ó Cuirrín uses figurative language to describe the unusual features of the Transylvanian Count. Many of the similes and metaphors used allude to the gothic architecture of Dracula's castle. Having described Dracula's mouth as a loving mouth, "g[h]ob grámhar" (Stoker 1997, 61), in contrast with the oxymoron "soft, smooth diabolical smile" (Stoker 1996, 49), Ó Cuirrín relies on three different techniques to describe the Count: alliteration, simile, and metaphor. In the space of 
an eight-clause paragraph, Ó Cuirrín uses six double alliterations, amongst them, "cumasach cromógach" [powerful and hook-nosed], "mursanta míthrócaireach" [tyrannous and merciless] (Stoker 1997, 22), "mílítheacht mhíchuibheasach" [pallid and unseemly], and "rinn róghéar" [tips that were too sharp] (Stoker 1997, 23). This compares with Stoker's "strong” and "aqualine” face (Stoker 1996, 17), his "extraordinary pallor," his "fixed and rather cruel-looking” countenance, and the tops of his ears as "extremely pointed." In addition to the lack of qualifiers such as "rather," the overall effect of alliteration in the Irish-language passage is one of onomatopoeia, achieved through Ó Cuirrín's use of Irish-language dentals. Fear and tension, then, are realized in Ó Cuirrín's translation not merely through word choice and alliteration but also by way of phonology. The grandeur of an arched doorway in the gothic style is alluded to in the employment of "stuadhorais" [arched doorway] (Stoker 1997, 22) to describe Dracula's nose, where Stoker uses the word "arched" as an adjective (Stoker 1996, 17), thereby emphasizing a central motif. The image of the arched doorway is significant when Jonathan realizes that he is trapped in Dracula's castle.

In this way, Ó Cuirrín's translation connects the reader to the gothic mode and to the plight in which Jonathan finds himself. The metaphor used by Ó Cuirrín in describing Dracula's lips as having the redness of a rose, "deirge an róis" (Stoker 1997, 23), comprises a poetic register in a prose passage. In addition, it has echoes of amour courtois poetry in Irish, where the features of the poet's love object were often compared to that of a rose. In this passage, however, Ó Cuirrín does not employ comparison; rather, he imbues Dracula with the beauty and vigour of youth through metaphor. Both these examples can be compared with the literal descriptions of Dracula in the English original, with little use of figurative language. In addition, the translation contains a pretext to Dracula and Jonathan's discussion of the history of the area and of Dracula's family's role in "the stirring times, when the Austrian and the Hungarian came up in hordes" (Stoker 1996, 21).

Mirroring is a technique used by Stoker in the narrative construction and in the recurring ideas of the novel to reflect the intersubjectivity of experience. Rita Felski comments how G. H. Mead's view of intersubjectivity, where the formation of the self involves all sorts of "messy entanglements" (Felski 2008, 32), implies that "No hardand-fast line can be drawn between our own selves and the selves of others" (Felski 2008, 32). The importance of newspapers and magazines in Dracula, as sources of “facts" (Stoker 1996, 30), reflects the extent to which a variety of forms of media and technology are harnessed by Stoker to narrate the story. Yet the epistolary narrative which is so prevalent in Dracula is, as Chatman notes, an "unmediated narrative text" and one where "secondary mediation is always possible" (Chatman 1978, 171). It serves Dracula in his private library and Jonathan Harker and his friends in their pursuit of Dracula. Similarly, while the mirror does not reflect Dracula's image to Jonathan, he can see himself clearly in it, and it functions as one of the 
means by which Dracula both hides and reveals himself. It is, in turn, the means by which Jonathan Harker reveals the materiality of his own physical self. The everincreasing self-doubts that Jonathan harbours confirm the idea of Transylvania as physical place and mental state. It is also, of course, one of the markers of the gothic novel, as Goss notes, where the "gothic novel can be read as a fragmented fable of identity" (2006, 79). Transylvania, then, does not represent a binary between a place and a mentality but becomes an interchangeable state of mind reflecting the characters' moods and fears back to themselves.

\section{The Transylvanian Landscape}

Ó Cuirrín's translation approach to Count Dracula amounts to what Jääskeläinen describes as a local strategy of translation (1999), where the text points towards a local anti-hero who is not immediately identifiable as Transylvanian. In contrast, his treatment of the Transylvanian landscape and the soundscape of terror aligns very closely with that of Stoker, in keeping with what Newmark terms synonymy in translation (1988). Ó Cuirrín's translation heightens the affective impact of landscape through the employment of a variety of techniques. Kiberd notes how the act of reading is "to enter a sort of exile from the world around us" $(2005,1)$. One could say that Jonathan has started his exile in Transylvania through the act of searching it out. The first indication of a journey to Transylvania as a trip to a place of anxiety and deep confusion is given in the opening section of the novel. This occurs when Jonathan realizes, during his sojourn to the British Library, that no maps exist of Dracula's Castle, which lies somewhere "in the extreme east of the country" (Stoker 1996, 1). Ó Cuirrín transliterates this statement. As in the Stoker original, the narrative in the Irish translation traces how Dracula's connections to the notion of Transylvania as a definitive place become ever more tenuous, to the extent that he is described late in the novel as coming from the "wolf country" (Stoker 1996, 324). Transylvania is "the very place where he have been alive" (Stoker 1996, 319), Van Helsing claims in broken English. This compares to Dracula's statement of identity at the outset of the novel, when he claims that "Transylvania is not England" (Stoker 1996, 27), again translated literally by Ó Cuirrín. The shock of who and what Dracula is resonates with Trilling's assertion (1965) regarding modern literature as the stuff of violence and destruction that threatens the foundations of civilization. Transylvania is the alma mater for that destruction, the castle in the mountains with its history of battles fought and won, appearing to offer a historical and class legitimacy not enjoyed by the ordinary citizens of London. The changing splendours of Transylvania and the oscillation between notions of beauty and beast are pronounced and constant. Indeed, the image of the mountain as essential to the gothic imagination is one that is replicated in both original and translation. As in 
other Irish-language gothic literature, the mountain wilderness replaces the castle as the primary site of the gothic. The Carpathian Mountains are both celebrated and feared: on the one hand, a country "full of beauty of every kind" (Stoker 1996, 2), on the other, the towering Carpathian mountains with their "endless perspective of jagged rock and pointed crags" (Stoker 1996, 7). Of significance in Ó Cuirrín’s Irish translation, however, is that the mountain is also used in metaphorical terms to describe Judgement Day, "Lá an tSléibhe" [the day of the mountain] (Stoker 1997, 79). The significance of this in Ó Cuirrín's translation is, of course, that the term appears in Mina's journal. Unknown to her, Jonathan is trapped in the Carpathian Mountains as she writes her diary.

Transylvania is always present in Dracula, even when the location is elsewhere. The middle chapters of the novel, set mostly in England, are as much about what differentiates it from Transylvania as they are about England itself. It is Transylvania which is written as a place of beauty rather than England. It is Transylvania which contains mystery and intrigue, which has as much variety of weather and climate as London has its multitudes. Pathetic fallacy in Dracula is one of the most central components of the novel: the weather changes from light to dark, from bright to overcast as the coach approaches Dracula's castle. Yet it is unclear whether the weather reflects the evil lurking in Transylvania, or whether the evil affects the weather.

In her analysis of surrealism in modern Irish prose literature, Máirín Nic Eoin $(2006,77)$ notes how akin it is to "ag taisteal gan mhapaí" [travelling without maps]. As it happens with many tropes and motifs throughout the novel, the opening scene in the British Library quoted above is reflected again when Jonathan finds himself in Dracula's library on the other side of Europe. In the same way that no maps exist of Dracula's locality in Transylvania, this early observation by Jonathan is the first in a series of insights into his own character. Despite the technological advances of phonographs, science, and writing, despite Harker and his circle being educated people, the novel suggests that they do not hear their own voices as much as they should. It is for this reason, perhaps, that McCormack suggests that Harker's surname functions in the novel as a "cypher" for hearing $(1991,843)$.

It is in the passages describing the mountains of Transylvania and evoking pathetic fallacy that we best witness Ó Cuirrín's exceptional talents as literary translator. Among the most beautifully written passages in the translation, the translator retains the lexical meaning of Stoker's original while keeping the structure of the original almost entirely intact. The only addition is Ó Cuirrín's predilection for alliteration, where "lofty steeps" are translated as "leaca lánarda" (Stoker 1996, 8). Connotations of English words are retained in their Irish form, and there is neither narrowing nor extension of the meaning of the words. The same mountain effects change, and Jonathan notices how it "seemed as if the mountain range had separated two atmospheres, and that now we had got into the thunderous one" (Stoker 1996, 7). It is from the same "beautiful range" that the sounds of howling wolves are heard 
(Stoker 1996, 7), and it is through the same lonely pass that Jonathan reflects on the devastating famine that killed so many in the region.

Transylvania, then, can be read both literally and figuratively, as much a state of mind and a mirror in which we see the underbelly of human depravity as a physical landscape and Dracula's home. The material comforts of the Castle, with its grand furniture and overwhelming opulence offer no recourse or relief to a distraught Jonathan. It dawns on him, as he sees the sun rising in the East, that the place in which he is residing has caused him to become a stranger to himself. The mirroring between Dracula and Jonathan is as evident in the Irish translation as in the English original. Dracula's words that he, the Count, will be a "stranger in a strange land" (Stoker 1996, 20) reflect how Jonathan starts "at my own shadow and am full of all sorts of horrible imaginings" (Stoker 1996, 33). This, in turn, reflects his references in Stoker's narrative to Hamlet's predicament, left untranslated by Ó Cuirrín (de Brún 2007): "Fiú mo scáil féin, baineann sí geit asam uaireanta agus tá mé ciaptha cráite ag smaointe dúra dorcha” (Stoker 1997, 42) [Even my own shadow, at times it frightens me, and I am tormented and harassed by dark, grim thoughts]. The absence of such speech in these passages is noteworthy. For example, speech is shown as concealing the truth, as when Jonathan realizes that the Count's words belie his true intentions towards him and when he notices that "his words and looks did not seem to accord" (Stoker 1996, 24). When Jonathan Harker looks out of the castle window and is met with the shouts of the local Szgany, their muted laughter serves to emphasize his own isolation as a prisoner in Dracula's Castle. Ironically, the sound of laughter is frequently treated by Ó Cuirrín as an isolating experience. In the Irish translation, he compares the howling of wolves to the sweetness of the music of the fairies: "Ba bhinne ná an ceol sí an gáire sin” (Stoker 1997, 47) [Their music was sweeter than fairy music]. Through the character of Harker, Ó Cuirrín includes a cultural reference in Irish folklore to both the wonder and the fear of the fairies.

\section{Conclusion}

Loss of plot in Ó Cuirrín’s translation of Dracula was Irish language’s gain. Ó Cuirrín’s creative flair for story frequently surpasses the Stoker original in terms of stylistic technique. The loss of intertextual layer and speech registers in the Irish translation is replaced by a masterly display of prose techniques, drawing as the translator does on amplification, alliteration, simile, proverb, and metaphor. Dracula's character, and the idea of Transylvania as a state of mind rather than a place akin to the classical underworld that is so prominent in Stoker's original, are enriched and re-imagined by the language of the Irish text. If adventure and the unknown were the common threads in much of the translated texts of the period of translation from 1926 to 2000, from Wuthering Heights to Dante's Inferno, the choice of Dracula for translation was 
an entirely appropriate one. Ó Cuirrín’s achievement was to create an Irish-language gothic, and, while it contains similarities to McCormack's description of "the Irish gothic" $(1991,831)$, the translator retains the essence of what Chatman calls story as events $(1978,43)$, where "the basic stuff" of story, the fabula is retained (1978, 19). As shown here, close reading reveals a literature brimming with allusion and tripping over itself with figurative and idiomatic language.

Felski $(2008,8)$ cautions critics and readers of literature against trying "to force an equivalence of textual structures with social structure, to assert a necessary causality between literary forms and larger political effects." And yet it is hard not to agree with Declan Kiberd when he notes how the Great Famine in Ireland must have influenced the young Stoker in writing Dracula (2006, 378). Dracula begins with a trip to Transylvania: the novel ends, somewhat inexplicably, with a short account of a return trip by Jonathan and Mina with their young son. Perhaps this, more than any other account in the novel, is an indication of how, just as Transylvania held them in a vice-grip of terror during the reign of Dracula and the Undead, continues to hold power over their imaginations. Having fought Dracula "for the sake of humanity" (Stoker 1996, 319), the dichotomy between Transylvania and England is perhaps a false one: all this time, it was a battle not between two places but between different states of mind and opposing values. At the end of our journey with the Irish-language translation, we can indeed conclude that we have been enriched by Ó Cuirrín’s prosodic brilliance. All along, Dracula was a novel as much about the inscrutability of language as it was about the gothic. Hidden in plain sight, Dracula challenges us to confront, as it did Ó Cuirrín, the gap between the concrete and the abstract, the material and the spiritual. It should come as no surprise, then, that the Irish translation of Dracula should take its place alongside this novel of "strange tongues, fierce-falling water, and the howling of wolves" (Stoker 1996, 345) to become a quintessentially Gaelic-Transylvanian text.

\section{Works Cited}

Ajoke, Alabere Rabiat, Hasan, Md. Kamrul, and Suleiman Yusuf. 2015. "Examining the Use of Proverbs in Teaching English as Second Language: An Implication for Secondary School Principals in Nigeria.” ELT VIBES: International E-Journal for Research in ELT vol. 1, no. 3: 14-28.

https://www.academia.edu/14207289/Examining_the_Use_of_Proverbs_in_ Teaching_English_as_Second_Language_An_Implication_for_Secondary_ School_Principals_in_Nigeria (last accessed: 6 July 2020).

Biber, Douglas. 2009. Register, Genre and Style. Cambridge: Cambridge Textbooks in Linguistics.

Brontë, Emily. 2017 [1847]. Wuthering Heights. London: Faber and Faber. 
Chatman, Seymour Benjamin. 1978. Story and Discourse: Narrative Structure in Fiction and Film. Ithaca: Cornell UP.

Cronin, Michael. 1993. "Movie-Shows from Babel: Translation and the Irish Language.” Irish Review no. 14 (Autumn): 56-64.

Dante Ailigiéiri. 1963. Coiméide dhiaga Dante, Leabhar 1 [Dante’s Divine Comedy, Book 1]. Transl. Pádraig de Brún. Dublin: Mac an Ghoill.

de Brún, Sorcha. 2007. "Dracula agus Seán Ó Cuirrín: Cuid 1. Ceisteanna cóirithe, téacsacha agus teanga” [Dracula and Seán Ó Cuirrín: Part 1: Questions of Translation, Text, and Language]. Bliainiris 7: 166-203.

2009. “Dracula agus Seán Ó Cuirrín: Cuid 2. Móitífeanna agus Miotais” [Dracula and Seán Ó Cuirrín: Part 2: Motifs and Myths]. Bliainiris 9: 112-152.Dundes, Alan and Wolfgang Mieder, eds. 1994. The Wisdom of Many: Essays on the Proverb. Wisconsin: University of Wisconsin Press.

Felski, Rita. 2008. Uses of Literature. Oxford: Blackwell Publishing.

Goss, Sarah. 2006. "Dracula and the Spectre of Famine.” In Images of Famine in the Irish Canon, ed. George Cusack, 77-107. Dublin: Irish Academic Press.

Haining, Peter and Peter Tremayne. 1997. The Un-Dead: The Legend of Bram Stoker and Dracula. London: Constable.

Hebron, Malcolm. 2004. Mastering the Language of Literature. Basingstone: Palgrave Macmillan.

Irving, Washington. 1909 [1819]. Rip Van Winkle. London and New York: William Heinemann and Doubleday Page \& Co.

Jääskeläinen, Riitta. 1999. Tapping the Process: An Explorative Study of Cognitive and Effective Factors Involved in Translating. Joensuu: University of Joensuu Publications in Humanities.

Kiberd Declan. 2005. The Irish Writer and the World. Cambridge: Cambridge University Press.

2006. Irish Classics. London: Granta Books.

Mag Shamhráin, Antain and Pádraic Ó Faracháin. 2003. Foilseacháin An Ghúim 1926-2000 [The Publication of An Gúm 1926-2000]. Dublin: An Gúm.

McCormack, W. J. 1991. "Irish Gothic and After." In The Field Day Anthology of Irish Writing 2, ed. Séamus Deane, 831-949. Derry: Field Day Publications.

Meyer, Robert T. 1952. “The Middle Irish 'Odyssey': Folktale, Fiction, or Saga?” Modern Philology vol. 50, no. 2: 73-78.

https://www.jstor.org/stable/435554?seq=1\#metadata_info_tab_contents (last accessed: 6 July 2020).

Mullan, John. 2006. How Novels Work. Oxford: Oxford University Press.

Newmark, Peter. 1988. Approaches to Translation. Hertfordshire: Prentice Hall.

Nic Eoin, Máirín. 2006. “Ag Taisteal Gan Mhapaí: An Ficsean Neamhréalaíoch agus Gníomh na Léitheoireachta” [Travelling without Maps: Surrealist Fiction and the Act of Reading]. In An Prós Comhaimseartha: Léachtaí Cholm Cille XXXVI 
[Contemporary Prose: Colmcille Lectures], ed. Aisling Ní Dhonnchadha, 77-111. Maynooth: An Sagart.

Ó Conchubhair, Brian. 2011. "An Gúm, the Free State and the Politics of the Irish Language." In Ireland, Design and Visual Culture: Negotiating Modernity 19221992, eds. Linda King and Elaine Sisson, 93-113. Cork: Cork University Press.

Ó Cuirrín, Seán. 1933. Dracula. Transl. Seán Ó Cuirrín. $1^{\text {st }}$ edition. Dublin: An Gúm. 1936. Beirt Dhéiseach: mar atá: sceul nua-ceaptha agus trí sceulta arna dtiontódh ó theangthacha eile [Two Natives of Waterford: An Original Story and Three Stories Translated from Other Languages]. Dublin: Oifig an tSoláthair. 1938. Psaltair na Rinne. [The Psalter of Ring.] Dublin: Oifig an tSoláthair.

Stoker, Bram. 1996 [1897]. Dracula. London and New York: Oxford University Press. 1997 [1933] Dracula. Transl. Seán Ó Cuirrín. $2^{\text {nd }}$ edition. Ed. Maolmhaodhóg Ó Ruairc. Dublin: An Gúm.

2014 [1933] Dracula. Transl. Seán Ó Cuirrín. $3^{\text {rd }}$ edition. Ed. Maolmhaodhóg Ó Ruairc. Dublin: An Gúm.

Titley, Alan. 1990. An tÚrscéal Gaeilge [The Irish-Language Novel]. Dublin: An Clóchomhar Tta.

Tolstoy, Leo. 1923 [1872]. "God Sees the Truth, But Waits.” In Twenty-Three Tales. Transl. Louise and Aylmer Maude, 1-9. London: Oxford University Press.

Trilling, Lionel. 1965. "On the Teaching of Modern Literature.” In Beyond Culture: Essays on Literature and Learning, 3-27. New York: Viking.

Uí Laighléis, Gearóidín. 2003. "Máirtín Ó Cadhain agus Sally Kavanagh” [Máirtín Ó Cadhain and Sally Kavanagh]. Bliainiris 3: 75-94. 